\title{
PENGARUH BIAYA BAHAN BAKU, BIAYA TENAGA KERJA LANGSUNG, DAN BIAYA OVERHEAD PABRIK TERHADAP HARGA JUAL PADA PERUSAHAAN MANUFAKTUR SEKTOR INDUSTRI BARANG KONSUMSI YANG TERDAFTAR DI BEI
}

\author{
Ade Pipit Fatmawati, Afra Al Mumtahanah
}

Program Studi D4 Akuntansi Keuangan, Politeknik Pos Indonesia adepipitfatmawati@gmail.com, almumtahanahafra2@gmail.com

\begin{abstract}
ABSTRAK
Perusahaan Sektor Industri Konsumsi merupakan perusahaan manufaktur yang memproduksi kebutuhan sehari-hari masyarakat. Adanya fenomena tentang kenaikan harga jual sehingga menarik minat penulis untuk meneliti lebih mendalam mengenai hal tersebut. Penelitian ini bertujuan untuk mengetahui pengaruh biaya bahan baku, biaya tenaga kerja langsung, dan biaya overhead pabrik terhadap harga jual pada perusahaan manufaktur sektor industri konsumsi yang terdaftar di BEI periode 2020, baik secara masing-masing maupun bersamaan. Penelitian ini yaitu penelitian kuantitatif. Hipotesis yang ditetapkan menggunakan uji dua pihak ( $t w o$ tailed). Teknik analisis yang digunakan uji normalitas, korelasi product moment, analisis korelasi berganda, analisis regresi linier berganda, analisis koefisien determinasi, uji t dan uji F. Perhitungan statistik menggunakan SPSS for windows version 26. Penelitian ini menunjukkan bahwa biaya bahan baku, biaya tenaga kerja langsung, dan biaya overhead pabrik berpengaruh signifikan terhadap harga jual, baik secara parsial maupun secara simultan.
\end{abstract}

Kata Kunci: Biaya Bahan Baku, Biaya Tenaga Kerja Langsung, Biaya Overhead Pabrik, Harga Jual.

\footnotetext{
ABSTRACT

Consumer Goods Industry Sector Companies are manufacturing companies that produce people's daily needs. There is a phenomenon about the increase in selling prices so that it attracts the interest of the author to research more deeply about it. This study aims to determine the effect of raw material costs, direct labor costs, and factory overhead costs on the selling price of manufacturing companies in the consumer goods industry sector listed on the Indonesia Stock Exchange for the 2020 period, either individually or simultaneously. This research is quantitative research. The hypothesis is determined using a two-tailed test (two-tailed). The analytical technique used is normality test, product moment correlation, multiple correlation analysis, multiple linear regression analysis, coefficient of determination analysis, $t$ test and $F$ test. Statistical calculations using SPSS for windows version 26. This study shows that the cost of raw materials, direct labor costs, and factory overhead costs have a significant effect on the selling price, either partially or simultaneously.

Keywords: Raw Material Cost, Direct Labor Cost, Factory Overhead Cost, Selling Price.
} 


\section{PENDAHULUAN}

Pada saat ini persaingan yang terjadi pada perusahaan manufaktur yaitu mengenai permasalahan penentuan biaya-biaya yang di keluarkan dalam proses produksi seperti biaya bahan baku, biaya tenaga kerja langsung, dan biaya overhead pabrik. Biaya- biaya tersebut termasuk sebagai biaya produksi yang berkaitan langsung dalam penentuan harga jual. Harga jual merupakan hasil dari total biaya produksi di tambahkan dengan margin yang telah ditentukan oleh perusahaan. Berdasarkan berita online yang di lansir CNBC Indonesia pada tanggal 18 maret 2020, Harga gula mengamuk ditengah panic buying corona dalam sebulan terakhir dipasar tradisional maupun pasar modern merangkak naik. Terdapat gejala yang membuktikan tertanggunya rantai pasok akibat wabah COVID-19 mengingat Indonesia masih mengimpor bahan baku gula untuk memenuhi kebutuhan dalam negeri. Bersumber pada data Pusat Informasi Harga Pangan Strategis (PIHPS) Nasional, harga gula baik dipasar tradisional maupun modern sudah berada di Rp16.800/kg. Padahal sebulan sebelumnya harga gula masih berada dikisaran Rp14.000 $\mathrm{Rp} 15.000 / \mathrm{kg}$. berikut tabel kenaikan harga gula dipasar tradisional maupun modern.

Tabel 1 Kenaikan Harga Gula

\begin{tabular}{|l|l|c|c|}
\hline \multicolumn{2}{|c|}{ Periode } & Harga Gula Premium & Harga Gula Lokal \\
\hline Februari 2020 & 19 & Rp15.250 & Rp14.250 \\
\hline & 25 & Rp15.350 & Rp14.400 \\
\hline & 27 & Rp15.400 & Rp14.500 \\
\hline Maret 2020 & 02 & Rp15.450 & Rp14.700 \\
\hline & 03 & Rp15.600 & Rp14.950 \\
\hline & 04 & Rp15.750 & Rp15.200 \\
\hline & 05 & Rp15.900 & Rp15.550 \\
\hline & 06 & Rp16.000 & Rp15.700 \\
\hline & 09 & Rp16.250 & Rp16.400 \\
\hline & 11 & $R p 16.450$ & Rp17.400 \\
\hline
\end{tabular}

Berdasarkan tabel 1.1 dalam sebulan terakhir harga gula di pasaran telah naik $10 \%$ $18 \%$. Ini merupakan peningkatan yang fantastis. Harga tersebut lebih besar dari harga acuan di tingkatan konsumen yang ditetapkan oleh Menteri Perdagangan. Dalam memenuhi kebutuhan gula nasional, Indonesia mengandalkan impor terutama Thailand dan Australia yang menyumbang lebih dari $98 \%$ total impor gula tanah air. Ada indikasi impor gula bulan Februari dari Thailand juga akan terganggu, mengingat jumlah kasus infeksi COVID-19 di Thailand bertambah banyak.

Harga jual senantiasa menjadi dimensi apakah seseorang hendak melakukan pembelian atau tidak. Sehingga apabila harga jual suatu produk naik maka, peminatnya akan berkurang, begitu sebaliknya. Sesuai dengan teori yang diungkapkan Sodikin dalam (Oktavia Toar, 2016) "Penentuan harga jual merupakan salah satu keputusan manajemen. Hidup matinya perusahaan dalam jangka panjang tergantung pada keputusan pricing ini”.

Penelitian ini mengacu pada penelitian terdahulu yang dilakukan oleh (Muhammad Iqbal, 2017) hasil penelitian tersebut menjelaskan bahwa biaya bahan baku, biaya tenaga kerja langsung, dan biaya overhead pabrik berpengaruh secara simultan terhadap harga jual. penelitian lain dilakukan oleh (Maftukhah, 2016) hasil penelitian menunjukkan bahwa tidak ada pengaruh antara biaya bahan baku, biaya tenaga kerja langsung, dan biaya overhead pabrik terhadap harga jual. selain itu (Agustina, 2017) juga melakukan penelitian bahwa biaya bahan baku, biaya tenaga kerja langsung, dan biaya overhead pabrik berpengaruh terhadap harga jual, dan penelitian lain di lakukan oleh (Rukmi Juwita, 2020) yang menghasilkan bahwa biaya pemeliharaan mesin berpengaruh terhadap harga jual. 
Berdasarkan uraian latar belakang yang telah dipaparkan diatas, maka penulis tertarik untuk melakukan penelitian dengan judul "Pengaruh Biaya Bahan Baku, Biaya Tenaga Kerja Langsung, dan Biaya Overhead Pabrik terhadap Harga Jual Pada Perusahaan Manufaktur Sektor Industri Barang Konsumsi yang terdaftar di BEI Periode 2020”.

Adapun identifikasi masalah dalam penelitian ini adalah sebagai berikut:

1. Bagaimana Pengaruh Biaya Bahan Baku terhadap Harga Jual pada Perusahaan Manufaktur Sektor Industri Barang Konsumsi yang terdaftar di BEI Periode 2020?

2. Bagaimana Pengaruh Biaya Tenaga Kerja Langsung terhadap Harga Jual pada Perusahaan Manufaktur Sektor Industri Barang Konsumsi yang terdaftar di BEI Periode 2020 ?

3. Bagaimana Pengaruh Biaya Overhead Pabrik terhadap Harga Jual pada Perusahaan Manufaktur Sektor Industri Barang Konsumsi yang terdaftar di BEI Periode 2020?

4. Bagaimana Pengaruh Biaya Bahan Baku, Biaya Tenaga Kerja Langsung, dan Biaya Overhead Pabrik terhadap Harga Jual pada Perusahaan Manufaktur Sektor Industri Barang Konsumsi yang terdaftar di BEI Periode 2020?

\section{KAJIAN PUSTAKA}

Variabel $\mathrm{X}$ yang digunakan dalam penelitian ini yaitu Biaya Bahan Baku, Biaya Tenaga Kerja Langsung, dan Biaya Overhead Pabrik. Menurut (Mulyadi, 2017) "Bahan baku merupakan bahan yang membentuk bagian menyeluruh produk jadi". Menurut (Mulyadi,2017) "Tenaga kerja merupakan usaha fisik maupun mental yang dikeluarkan karyawan untuk mengolah produk. Biaya tenaga kerja adalah harga yang dibebankan untuk penggunaan tenaga kerja kerja manusia tersebut. Menurut (Mulyadi,2017) "Biaya overhead pabrik adalah biaya produksi selain biaya bahan baku dan biaya tenaga kerja langsung".

Sedangkan variabel $Y$ yang digunakan dalam penelitian ini yaitu Harga Jual. Menurut (Sujarweni V.W, 2019) "Harga jual adalah sejumlah uang yang dibebankan atas suatu produk atau jasa, atau jumlah dari nilai yang ditukar konsumen atas manfaat-manfaat, karena memiliki atau menggunakan produk atau jasa tersebut". Adapaun rumus penentuan harga jual yaitu sebagai berikut:

\section{Rumus Harga Jual Total \\ METODE PENELITIAN
Metode Penelitian}

Penelitian ini menggunakan metode asosiatif yang bersifat kausal karena penelitian ini berupa angka-angka dan mencari hubungan sebab akibat atau pengaruh dari empat variabel yaitu variabel bebas terdiri dari biaya bahan baku, biaya tenaga kerja langsung, dan biaya overhead pabrik, dan variabel terikat yaitu harga jual.

\section{Operasional Variabel}

Berdasarakan judul yang telah dijelaskan pada bab sebelumnya yaitu "Pengaruh Biaya Bahan Baku, Biaya Tenaga Kerja Langsung, dan Biaya Overhead Pabrik terhadap Harga Jual Pada Perusahaan Manufaktur Sektor Industri Barang Konsumsi Yang Terdaftar di BEI Periode 2020". Penelitian ini memiliki 4 (empat) variabel yang saling berkaitan yaitu variabel bebas (independent variable) yaitu biaya bahan baku, biaya tenaga kerja langsung, dan biaya overhead pabrik, dan variabel terikat (dependent variable) yaitu harga jual.

\section{Teknik Pengumpulan Data}

Metode pengumpulan dalam penelitian ini di peroleh dari studi kepustakaan melalui sumber-sumber buku, jurnal terdahulu yang sesuai dengan penelitian sebagai upaya untuk memeperoleh data yang valid dan studi dokumentasi. Dalam penelitian ini sumber data 
yang digunakan adalah sumber data sekunder, data-data di peroleh melalui website resmi Bursa Efek Indonesia (BEI).

\section{Populasi dan sampel}

Adapun populasi dalam penelitian ini yaitu seluruh laporan keuangan perusahaan manufaktur sektor industri barang konsumsi yang terdaftar di BEI yang terdiri dari 53 perusahaan. Teknik sampling yang digunakan dalam penelitian ini adalah metode non probability sampling dengan pendekatan purposive sampling. Sampel dalam penelitian ini terdiri dari 47 perusahaan manufaktur sektor industri barang konsumsi yang terdaftar di BEI.

\section{Teknik Analisis Data}

Teknik analisis data yang dilakukan dalam penelitian ini adalah analisis kuantitatif dengan menggunakan perangkat lunak Microsoft excel dan program SPSS for windows version 26. Teknik analisis data yang digunakan dalam penelitian ini terdiri dari uji normalitas data, korelasi product moment, korelasi berganda, analisis regresi linier berganda, uji t, uji F, dan koefisien determinasi.

\section{HASIL DAN PEMBAHASAN}

\section{Uji Normalitas}

Uji normalitas data digunakan dengan tujuan untuk mengetahui distribusi dalam variabel yang akan digunakan dalam penelitian. Data yang layak dan baik digunakan dalam penenlitian adalah data yang berdistribusi normal. Pengujian normalitas data menggunakan Test of Normality Kolmogorov Smirnov dengan SPSS for windows version 26.

Tabel 2 Uji Normalitas Data

One-Sample Kolmogorov-Smirnov Test

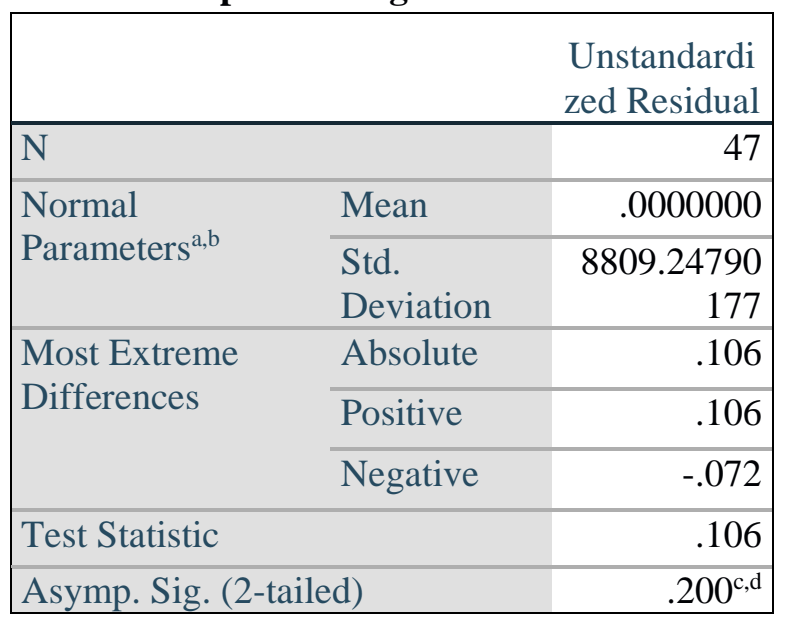

Berdasarkan hasil uji normalitas dengan bantuan software SPSS 26 for windows diperoleh nilai signifikan sebesar $0.200>0.050$, maka dapat disimpulkan bahwa data yang diperoleh berdistribusi normal.

\section{Korelasi Product Moment}

Korelasi Product Moment digunakan untuk mencari arah kuatnya hubungan dari masing-masing variabel bebas dan variabel terikat. Pengujian korelasi product moment menggunakan Test of Normality Kolmogorov Smirnov dengan SPSS for windows version 26.

Tabel 3 Korelasi Product Moment Correlations 


\begin{tabular}{|c|c|c|c|c|c|}
\hline & & $\begin{array}{c}\text { Biaya } \\
\text { Bahan } \\
\text { Baku } \\
\end{array}$ & $\begin{array}{c}\text { Biaya Tenaga } \\
\text { Kerja } \\
\text { Langsung } \\
\end{array}$ & $\begin{array}{c}\text { Biaya } \\
\text { Overhead } \\
\text { Pabrik }\end{array}$ & $\begin{array}{c}\text { Harga } \\
\text { Jual }\end{array}$ \\
\hline \multirow[t]{3}{*}{$\begin{array}{l}\text { Biaya Bahan } \\
\text { Baku }\end{array}$} & $\begin{array}{l}\text { Pearson } \\
\text { Correlation }\end{array}$ & 1 & $.977^{* * *}$ & $.981^{* *}$ & $.997^{* *}$ \\
\hline & Sig. (2-tailed) & & .000 & .000 & .000 \\
\hline & $\mathrm{N}$ & 47 & 47 & 47 & 47 \\
\hline \multirow{3}{*}{$\begin{array}{l}\text { Biaya Tenaga } \\
\text { Kerja } \\
\text { Langsung }\end{array}$} & $\begin{array}{l}\text { Pearson } \\
\text { Correlation }\end{array}$ & $.977^{* * *}$ & 1 & $.984^{* *}$ & $.985^{* *}$ \\
\hline & Sig. (2-tailed) & .000 & & .000 & .000 \\
\hline & $\mathrm{N}$ & 47 & 47 & 47 & 47 \\
\hline \multirow{3}{*}{$\begin{array}{l}\text { Biaya } \\
\text { Overhead } \\
\text { Pabrik }\end{array}$} & $\begin{array}{l}\text { Pearson } \\
\text { Correlation }\end{array}$ & $.981^{* *}$ & $.984^{* *}$ & 1 & $.991^{* * *}$ \\
\hline & Sig. (2-tailed) & .000 & .000 & & .000 \\
\hline & $\mathrm{N}$ & 47 & 47 & 47 & 47 \\
\hline \multirow[t]{3}{*}{ Harga Jual } & $\begin{array}{l}\text { Pearson } \\
\text { Correlation }\end{array}$ & $.997^{* *}$ & $.985^{* *}$ & $.991^{* *}$ & 1 \\
\hline & Sig. (2-tailed) & .000 & .000 & .000 & \\
\hline & $\mathrm{N}$ & 47 & 47 & 47 & 47 \\
\hline
\end{tabular}

Berdasarkan hasil pengolahan data korelasi product moment menggunakan SPSS for windows version 26.00, diketahui dari koefisien korelasi bahwa biaya bahan baku (X1) berhubungan secara positif terhadap harga jual $(\mathrm{Y})$ dengan nilai 0,997 yang berada pada interval 0,800 - 1,000 yang mana dapat diartikan bahwa hubungan antara biaya bahan baku (X1) sebagai variabel independen terhadap harga jual (Y) sebagai variabel dependen sangat kuat.

Untuk biaya tenaga kerja langsung (X2) berhubungan secara positif terhadap harga jual (Y) dengan nilai 0.985 yang berada pada interval $0,800-1,000$ yang mana dapat diartikan bahwa hubungan antara biaya tenaga kerja langsung (X2) sebagai variabel independen terhadap harga jual (Y) sebagai variabel dependen sangat kuat .

Sedangkan untuk biaya overhead pabrik (X3) berhubungan secara positif terhadap harga jual (Y) dengan nilai 0,991 yang berada pada interval 0,800 - 1,000 yang mana dapat diartikan bahwa hubungan antara biaya overhead pabrik (X3) sebagai variabel independen terhadap harga jual (Y) sebagai variabel dependen sangat kuat.

\section{Korelasi Ganda}

Korelasi ganda ini merupakan angka yang menunjukan arah dan kuatnya hubungan antara dua variabel independen secara bersama-sama atau lebih dengan satu variabel dependen.

Tabel 4 Korelasi Ganda

Model Summary ${ }^{\mathbf{b}}$

\begin{tabular}{|c|c|c|c|c|c|c|c|c|c|}
\hline \multirow[b]{2}{*}{ Model } & & \multirow[b]{2}{*}{$\begin{array}{c}\mathrm{R} \\
\text { Squar } \\
\mathrm{e}\end{array}$} & \multirow[b]{2}{*}{$\begin{array}{l}\text { Adjusted } \\
\text { R Square }\end{array}$} & \multirow[b]{2}{*}{$\begin{array}{l}\text { Std. Error of } \\
\text { the Estimate }\end{array}$} & \multicolumn{5}{|c|}{ Change Statistics } \\
\hline & & & & & $\begin{array}{c}\mathrm{R} \\
\text { Square } \\
\text { Change }\end{array}$ & $\begin{array}{c}\text { F } \\
\text { Change }\end{array}$ & df1 & $\begin{array}{l}\text { df } \\
2\end{array}$ & $\begin{array}{l}\text { Sig. F } \\
\text { Change }\end{array}$ \\
\hline 1 & .985 & .970 & .968 & 9111.36657 & .970 & $\begin{array}{r}463.24 \\
0\end{array}$ & 3 & 43 & .000 \\
\hline
\end{tabular}

Berdasarkan hasil pengolahan data dapat dilihat bahwa angka $\mathrm{R}$ sebesar 0,985, menunjukan bahwa terdapat hubungan yang sangat kuat antara biaya bahan baku(X1), 
biaya tenaga kerja langsung (X2), dan biaya overhead pabrik (X3) terhadap harga jual (Y). $\mathrm{Hal}$ ini terbukti dengan nilai $\mathrm{R}$ berada pada interval $0,800-1,000$, yang artinya tingkat hubungan antara variabel independen dengan variabel dependen adalah sangat kuat.

\section{Analisis Regresi Ganda}

Analisis regresi linear ganda digunakan untuk mengetahui arah hubungan antara variabel independen dengan variabel dependen apakah masing-masing variabel independen berhubungan positif atau negatif dan untuk memprediksi nilai dari variabel dependen apabila nilai independen mengalami kenaikan atau penurunan.

\section{Tabel 5 Analisis Regresi Ganda}

Coefficients $^{\mathrm{a}}$

\begin{tabular}{|c|c|c|c|c|c|}
\hline \multirow[b]{2}{*}{ Model } & \multicolumn{2}{|c|}{$\begin{array}{l}\text { Unstandardized } \\
\text { Coefficients }\end{array}$} & \multirow[t]{2}{*}{$\begin{array}{c}\text { Standardiz } \\
\text { ed } \\
\text { Coefficient } \\
\text { s } \\
\text { Beta }\end{array}$} & \multirow[b]{2}{*}{$\mathrm{T}$} & \multirow[b]{2}{*}{ Sig. } \\
\hline & B & Std. Error & & & \\
\hline 1 (Constant) & $\begin{array}{r}- \\
38155064.3 \\
98\end{array}$ & $\begin{array}{r}74093705.1 \\
45\end{array}$ & & -.515 & .609 \\
\hline Biaya Bahan Baku & .894 & .039 & .645 & $\begin{array}{r}22.72 \\
3\end{array}$ & .000 \\
\hline $\begin{array}{l}\text { Biaya Tenaga Kerja } \\
\text { Langsung }\end{array}$ & 1.721 & .555 & .095 & 3.101 & .003 \\
\hline Biaya Overhead Pabrik & 1.853 & .235 & .265 & 7.879 & .000 \\
\hline
\end{tabular}

Dari hasil pengolahan data diatas, sehingga dapat diketahui persamaan regresi antara biaya bahan baku, biaya tenaga kerja langsung, dan biaya overhead pabrik terhadap harga jual (Y) adalah sebagai berikut:

$$
\begin{gathered}
Y=a+b_{1} X_{1}+b_{2} X_{2}+b_{3} X_{3} \\
Y=\text {-38155064428,983+ 0,894X } X_{1}+1,721 X_{2}+1,853 X_{3} \\
\hline
\end{gathered}
$$

Dimana:

$$
\begin{aligned}
& \text { Y = Harga Jual } \\
& \text { a } \quad \text { Konstanta } \\
& \text { b1 b2 dan b3 = Koefisien Regresi } \\
& \mathrm{X} 1=\text { Biaya Bahan Baku } \\
& \text { X2 = Biaya Tenaga Kerja Langsung } \\
& \text { X3 = Biaya Overhead Pabrik }
\end{aligned}
$$

Dari persamaan regresi tersebut, dapat diartikan sebagai berikut:

1. Jika variabel Biaya Bahan Baku (X1), Biaya Tenaga Kerja Langsung (X2), dan Biaya Overhead Pabrik (X3) nilainya $=0$, maka nilai variabel Harga Jual (Y) adalah sebesar konstanta atau sebesar -38155064428,983 (dalam satuan hitung Rp). Dengan kata lain tidak akan memberikan pengaruh terhadap harga jual.

2. Koefisien regresi variabel Biaya Bahan Baku (X1) sebesar 0,894. Artinya jika Biaya Bahan baku mengalami kenaikan sebesar 1 (dalam satuan hitung Rp), mengakibatkan nilai variabel harga jual meningkat sebesar 0,894 (dalam satuan hitung Rp).

3. Koefisien regresi variabel Biaya Tenaga Kerja Langsung (X2) sebesar 1,721. Artinya jika Biaya Tenaga Kerja Langsung mengalami kenaikan 1 (dalam satuan hitung Rp) mengakibatkan harga jual meningkat sebesar 1,721 (dalam satuan hitung Rp). 
4. Koefisien regresi variabel Biaya Overhead Pabrik (X3) sebesar 1,853. Artinya jika Biaya Overhead Pabrik mengalami kenaikan 1 (dalam satuan hitung Rp) mengakibatkan harga jual meningkat sebesar 1,853 (dalam satuan hitung Rp).

\section{Pengujian Hipotesis}

Pengujian hipotesis ini digunakan menguji hipotesis yang telah dibuat oleh peneliti. Hipotesis ini diuji dengan Uji t dan Uji F untuk mengetahui signifikansi pengaruh variabel independen terhadap variabel dependen.

\section{a. Uji t (Uji Parsial)}

Uji t digunakan untuk mengetahui apakah terdapat pengaruh antar variabel independen (X) dengan variabel dependen (Y) secara parsial atau individual. Dalam penelitian ini menggunakan uji dua pihak (two tails test).

Tabel 6 Uji Parsial (uji t)

Coefficients $^{\mathrm{a}}$

\begin{tabular}{|c|c|c|c|c|c|}
\hline \multirow[b]{2}{*}{ Model } & \multicolumn{2}{|c|}{ Unstandardized Coefficients } & \multirow{2}{*}{$\begin{array}{l}\text { Standardize } \\
\text { d } \\
\text { Coefficients } \\
\text { Beta }\end{array}$} & \multirow[b]{2}{*}{$\mathrm{t}$} & \multirow[b]{2}{*}{ Sig. } \\
\hline & B & Std. Error & & & \\
\hline 1 (Constant) & $38155064.398^{-}$ & 74093705.145 & & -.515 & .609 \\
\hline Biaya Bahan Baku & .894 & .039 & .645 & $\begin{array}{r}22.72 \\
3\end{array}$ & .000 \\
\hline $\begin{array}{l}\text { Biaya Tenaga Kerja } \\
\text { Langsung }\end{array}$ & 1.721 & .555 & .095 & 3.101 & .003 \\
\hline Biaya Overhead Pabrik & 1.853 & .235 & .265 & 7.879 & .000 \\
\hline
\end{tabular}

Berdasarkan hasil perhitungan tabel diatas, menunjukan dari masing-masing variabel

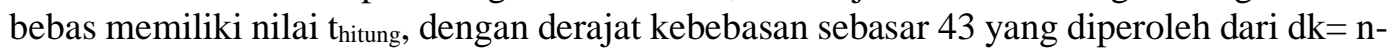
$\mathrm{k}(\mathrm{dk}=47-4=43)$ dengan signifikan 5\% atau 0,50. Sehingga diperoleh nilai $\mathrm{t}_{\text {tabel }}$ sebesar 2,0167. Berdasarkan pengujian hipotesis tersebut dapat diuraikan sebagai berikut:

\section{Biaya Bahan Baku terhadap Harga Jual}

Berdasarkan hasil perhitungan SPSS for windows version 26, diperoleh nilai $t_{\text {hitung }}$ sebesar 22,723. Maka nilai $t_{\text {hitung }}$ lebih besar dari $t_{\text {tabel }}$ yaitu 22,723 > 2,0167 dengan interpretasi $\mathrm{Ha}$ diterima $\mathrm{H}_{\mathrm{o}}$ ditolak yang memberikan arti bahwa terdapat pengaruh yang signifikan variabel biaya bahan baku (X1) terhadap harga jual (Y).

\section{Biaya Tenaga Kerja Langsung terhadap Harga Jual}

Berdasarkan hasil perhitungan SPSS for windows version 26, diperoleh nilai thitung sebesar 3.101. Maka nilai $t_{\text {hitung }}$ lebih besar dari $t_{\text {tabel }}$ yaitu 3,101 > 2,0167 dengan interpretasi $\mathrm{Ha}$ diterima $\mathrm{H}_{\mathrm{o}}$ ditolak yang memberikan arti bahwa terdapat pengaruh yang signifikan variabel biaya tenaga kerja langsung (X2) terhadap harga jual (Y).

\section{Biaya Overhead Pabrik terhadap Harga Jual}

Berdasarkan hasil perhitungan SPSS for windows version 26, diperoleh nilai thitung sebesar 7,879. Maka nilai $t_{\text {hitung }}$ lebih besar dari $t_{\text {tabel }}$ yaitu $7,879>2,0167$ dengan interpretasi Ha diterima $\mathrm{H}_{\mathrm{o}}$ ditolak yang memberikan arti bahwa terdapat pengaruh yang signifikan variabel biaya overhead pabrik (X3) terhadap harga jual (Y).

\section{b. Uji f (Uji Simultan)}

Uji F digunakan untuk menunjukan pengaruh dari seluruh variabel independen secara bersama-sama terhadap variabel dependen.

\section{Tabel 7 Uji Simultan (Uji F)}


ANOVA $^{\mathrm{a}}$

\begin{tabular}{|lrr|r|r|r|r|}
\hline Model & Sum of Squares & df & Mean Square & F & Sig. \\
\hline 1 & Regression & 115370376152.5 & 3 & 38456792050.8 & 463.24 & .000 \\
& 14 & & 38 & 0 & $\mathrm{~b}$ \\
\hline Residual & 3569731035.359 & 43 & 83017000.822 & & \\
\hline Total & 118940107187.8 & 46 & & & \\
\hline & 73 & & & & \\
\hline
\end{tabular}

Berdasarkan perhitungan SPSS for windows version 26.00 , maka didapat nilai $\mathrm{F}_{\text {hitung }}$ sebesar 463,240 dengan derajat kebebasan (dk) sebagai berikut:

$$
\begin{array}{rlrl}
\text { (Pembilang) } \mathrm{dk} 1=\mathrm{k} & \text { (Penyebut) dk } 2 & =\mathrm{n}-\mathrm{k}-1 \\
\mathrm{dk} 1 & =3 & \mathrm{dk} 2 & =47-3-1 \\
\mathrm{dk} 2 & =43
\end{array}
$$

dapat dilihat dalam $\mathrm{F}_{\text {tabel }}$ yaitu sebesar 2,82, sehingga dapat ditentukan bahwa nilai $\mathrm{F}_{\text {hitung }}$ lebih besar dari nilai $\mathrm{F}_{\text {tabel }}\left(\mathrm{F}_{\text {hitung }} 463,240>\mathrm{F}_{\text {tabel }}\right.$ 2,82) dengan nilai signifikansi ketiga variabel adalah $0,000<0,05$, maka dapat disimpulkan bahwa Ha diterima Ho ditolak. Artinya, biaya bahan baku, biaya tenaga kerja langsung, dan biaya overhead pabrik secara bersama-sama (simultan) berpengaruh positif yang signifikan terhadap harga jual.

\section{KESIMPULAN}

Berdasarkan hasil analisis data dan pembahasan mengenai penelitian ini, maka penulis dapat menarik kesimpulan, yaitu sebagai berikut:

1. Dalam hasil uji hipotesis secara parsial antara variabel Biaya Bahan Baku (X1) terhadap variabel Harga Jual (Y) menunjukkan bahwa terdapat pengaruh positif yang signifikan antara biaya bahan baku terhadap harga jual pada perusahaan manufaktur sektor industri konsumsi yang terdaftar di BEI periode 2020.

2. Dalam hasil uji hipotesis secara parsial antara variabel Biaya Tenaga Kerja Langsung (X2) terhadap variabel Harga Jual (Y) menunjukkan bahwa terdapat pengaruh positif yang signifikan antara biaya tenaga kerja langsung terhadap harga jual pada perusahaan manufaktur sektor industri konsumsi yang terdaftar di BEI periode 2020.

3. Dalam hasil uji hipotesis secara parsial antara variabel Biaya Overhead Pabrik (X3) terhadap variabel Harga Jual (Y) menunjukkan bahwa terdapat pengaruh positif yang signifikan antara biaya overhead pabrik terhadap harga jual pada perusahaan manufaktur sektor industri konsumsi yang terdaftar di BEI periode 2020.

4. Dalam uji hipotesis secara simultan antara variabel Biaya Bahan Baku (X1), Biaya Tenaga Kerja Langsung (X2), dan Biaya Overhead Pabrik (X3) terhadap Harga Jual (Y) menunjukkan bahwa secara simultan terdapat pengaruh positif yang signifikan antara biaya bahan baku, biaya tenaga kerja langsung, dan biaya overhead pabrik terhadap harga jual pada perusahaan manufaktur sektor industri barang konsumsi yang terdaftar di BEI periode 2020.

\section{SARAN}

Berdasarkan kesimpulan diatas, penulis mencoba memberikan saran yang dapat memberikan manfaat bagi peneliti selanjutnya. Adapun saran tersebut adalah sebagai berikut:

1. Peneliti selanjutnya disarankan supaya memperbaiki kekurangan-kekurangan yang terdapat dalam penelitian ini, yang tertarik dengan tema yang sama yaitu Akuntansi Biaya.

2. Peneliti selanjutnya diharapkan memperluas penelitian di berbagai sektor perusahaan dan periode tahunnya sehingga mendapat hasil data yang lebih baik. 
3. Bagi peneliti selanjutnya, disarankan agar peneliti dapat menambahkan atau merubah variabel Y (Dependen) lagi selain Harga Jual untuk lebih mengetahui variabel Y lain yang dapat dipengaruhi oleh biaya bahan baku, biaya tenaga kerja langsung, dan biaya overhead pabrik.

\section{DAFTAR PUSTAKA}

Agustina, N. (2017). Analisis Pengaruh Biaya Produksi terhadap Penentuan Harga Jual Produk (Studi kasus pada CV. Bambu Mandiri).

Citradi, T. (2020, Maret 18). Diambil kembali dari CNBC Indonesia: https://www.cnbcindonesia.com/news/20200317151131-4-145534/harga-gula-

mengamuk-di-tengah-panic-buying-corona

Juwita, R. (2020). Pengaruh Biaya Pemeliharaan Mesin Produksi Injection terhadap Harga Jual Produk Kursi Plastik (BIg101) pada PT. Cahaya Buana Intitama Bogor. Logistic and accounting development journal.

Maftukhah, R. (2016). Pengaruh Biaya Produksi Dalam Menentukan Harga Jual Pada Pabrik Bantal dan Kasur Lantai "sapanyana" Desa Dawuhan Wetan, Kedungbanteng, Banyumas, Jawa Tengah.

Muhammad Iqbal, D. P. (2017). Pengaruh Biaya Bahan Baku, Biaya Tenaga Kerja Langsung, dan Biaya Overhead terhadap Harga Jual Roti. Jurnal Ilmiah Akuntansi.

Oktavia Toar, H. K. (2016). Analisis Perbandingan Harga Jual Produk Dengan Menggunakan Metode Cost Plus Pricing dan Mark Up Pricing Pada Dolphin Donuts Bakery. Jurnal EMBA.

Sujarweni, V. W. (2019). Akuntansi Biaya. In Mona (Ed). Pustaka Baru Press. 